\begin{tabular}{|c|c|c|c|c|c|}
\hline \multirow{3}{*}{$\begin{array}{l}\text { 2. ECN Category } \\
\text { (mark one) } \\
\text { Supplenental } \\
\text { Direct Revision } \\
\text { Change E[N } \\
\text { Iemporary } \\
\text { standby } \\
\text { Supersedure } \\
\text { Cancel/Noid }\end{array}$} & \multicolumn{2}{|c|}{$\begin{array}{l}\text { 3. Originator's Name, Organization, MSIN, } \\
\text { and Telephone Ho. } \\
\text { R. M. Marusich, SA\&NE, A3-34 }\end{array}$} & \multicolumn{2}{|c|}{ 4. USO Required? } & $\begin{array}{l}\text { 5. Date } \\
09 / 19 / 96\end{array}$ \\
\hline & \multicolumn{2}{|c|}{$\begin{array}{l}\text { 6. Project Title/No./Work Order No. } \\
\text { TWRS FSAR/BIO }\end{array}$} & \multicolumn{2}{|c|}{$\begin{array}{l}\text { 7. Bldg./Sys./Fac. Wo. } \\
\text { TWRS }\end{array}$} & $\begin{array}{l}\text { B. Approval Designator } \\
\qquad A\end{array}$ \\
\hline & \multicolumn{2}{|c|}{$\begin{array}{l}\text { 9. Document Numbers Changed by this ECN } \\
\text { (includes sheet no. and rev.) } \\
\text { WHC-SD-WM-CN-051, ReV. } 0\end{array}$} & \multicolumn{2}{|c|}{$\begin{array}{l}\text { 10. Related ECN No(s) } \\
\qquad N / A\end{array}$} & $\begin{array}{l}\text { 11. Related PO No. } \\
\text { N/A }\end{array}$ \\
\hline \multirow{2}{*}{$\begin{array}{l}\text { 12a. Modificstion Work } \\
\text { [] Yes (fill out Blk. } \\
12 b) \\
{[X] \text { No (NA Blks. 12b, }} \\
12 c, 12 d)\end{array}$} & \multirow[t]{2}{*}{$\begin{array}{l}\text { 12b. Work Package } \\
\text { No. } \\
\text { N/A }\end{array}$} & \multicolumn{2}{|c|}{$\begin{array}{l}\text { 12c. Modification Work Complete } \\
\text { N/A }\end{array}$} & \multicolumn{2}{|c|}{$\begin{array}{l}\text { 12d. Restored to Original Condi- } \\
\text { tion (Temp. or Standby ECM only) } \\
\text { N/A }\end{array}$} \\
\hline & & \multicolumn{2}{|c|}{$\begin{array}{l}\text { Design Authority/Cog. Engineer } \\
\text { Signature \& Date }\end{array}$} & \multicolumn{2}{|c|}{$\begin{array}{l}\text { Design Authority/Cog. Engineer } \\
\text { Signature \& Date }\end{array}$} \\
\hline \multicolumn{6}{|c|}{$\begin{array}{l}\text { Editorial changes made. } \\
\text { References are more appropriate. }\end{array}$} \\
\hline \multicolumn{6}{|c|}{ 14a. Justificetion (merk one) } \\
\hline $\begin{array}{ll}\text { Criteria Change } & {[X]} \\
\text { As-Found } & {[]}\end{array}$ & Design Improvement & $\begin{array}{ll}\text { [] Environment } \\
\text { [] } & \text { Const. Erro }\end{array}$ & mission & \multicolumn{2}{|c|}{ Facility Deactivation } \\
\hline \multicolumn{6}{|l|}{$\begin{array}{l}\text { 14b. Justification Details } \\
\text { N/A }\end{array}$} \\
\hline \multicolumn{6}{|c|}{$\begin{array}{l}\text { 15. Distribution (include nane, MSIM, and no. of copies) } \\
\text { See attached. }\end{array}$} \\
\hline
\end{tabular}




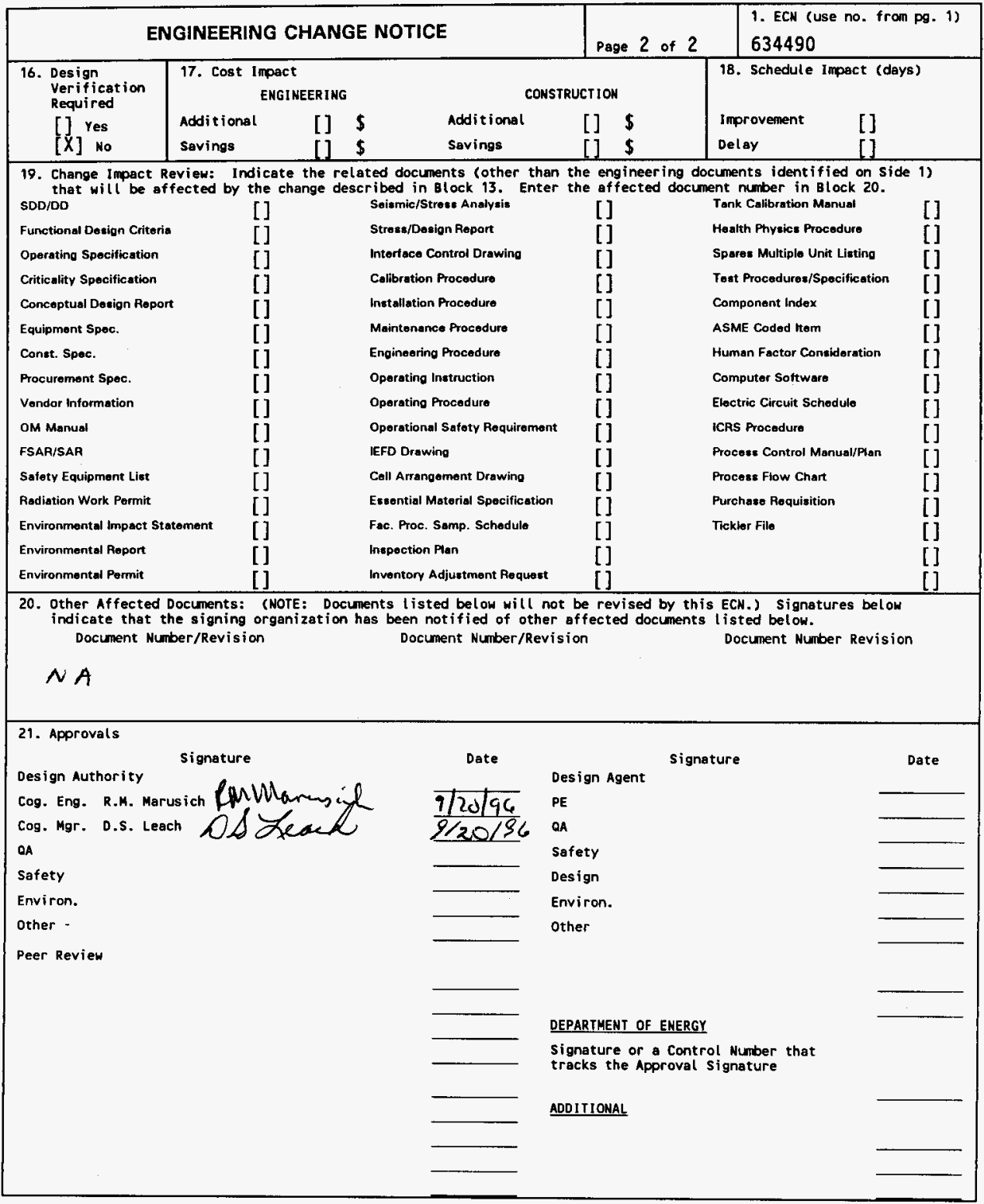




\title{
THE EFFECTS OF LOAD DROP, UNIFORM LOAD AND CONCENTRATED LOADS ON WASTE TANKS
}

\author{
R. M. Marusich
}

Westinghouse Hanford Company, Richland, WA 99352

U.S. Department of Energy Contract DE-AC06-87RL.10930

$\begin{array}{lll}\text { EDT/ECN: } & 634490 & \text { UC: } 510 \\ \text { Org Code: } & 8 M 400 & \text { Charge Code: N1FC3 } \\ \text { B\&R Code: } & \text { EW312007l } & \text { Total Pages: }\end{array}$

Key Words: Crane, Loads, Drop, Structural Failure

Abstract: This document provides the supporting calculations performed by others specifically for the TWRS FSAR and more detailed summaries of the important references issued in the past regarding the effects of various loads.

TRADEMARK DISCLAIMER. Reference herein to any specific commercial product, process, or service by trade name, trademark, manufacturer, or otherwise, does not necessarily constitute or imply its endorsement, recommendation, or favoring by the United States Government or any agency thereof or its contractors or subcontractors.

Printed in the United States of America. To obtain copies of this document, contact: WHC/BCS Document Control Services, P.O. Box 1970, Mailstop H6-08, Richland WA 99352, Phone (509) 372-2420; Fax (509) 376-4989.
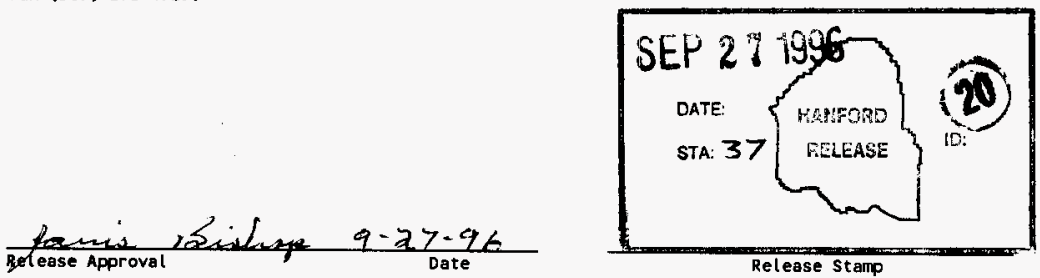

\section{Approved for Public Release}


RECORD OF REVISION

(1) Document Number

WHC-SD-WM-CN-051

Page 1

(2) Title

The Effects of Load Drop, Uniform Load and Concentrated Load on Waste Tanks

CHANGE CONTROL RECORD

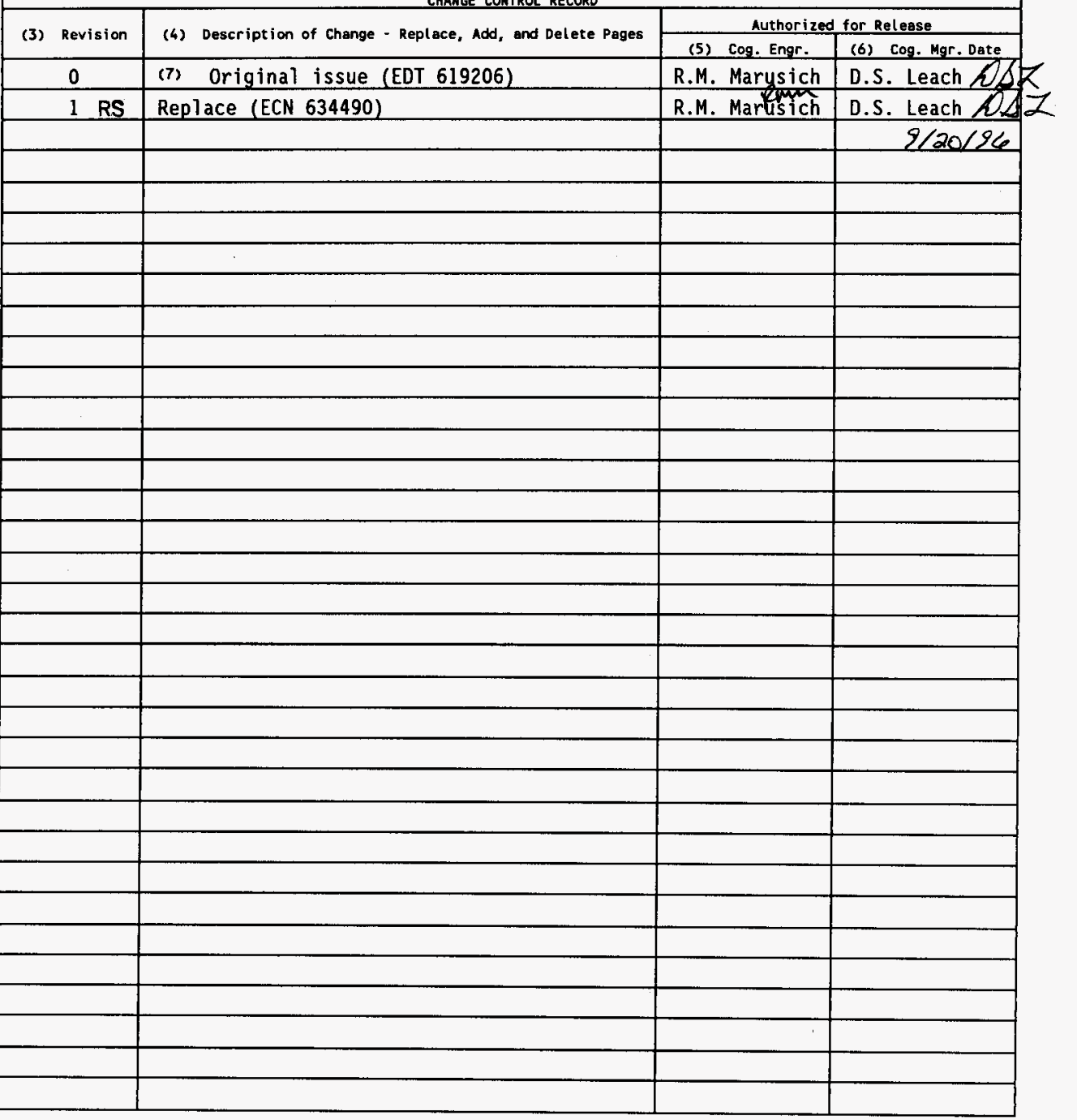


THE EFFECTS OF LOAD DROP, UNIFORM LOAD AND CONCENTRATED LOADS ON WASTE TANKS REVISION 1

Tank Waste Remediation System

Final Safety Analysis Report

Safety Analysis and Nuclear Engineering Group

August 
WHC-SD-WM-CN-051 REV 1

This page intentionally left blank 
1. Purpose

The purpose of this Calc Note is to provide a referenceable document for the "dome collapse" consequences. Dome collapse can be due to a drop of a heavy load or the placement of an excessive uniform or concentrated load.

\subsection{Methodology}

The methodology used in this analysis is of two types. There is the structural response to the load and there is the calculation of respirable material released to the environment (with dose consequences).

The structural response for the excess concentrated load comes from Han (1996) and for the load drop; from Julyk (1996). For the load drop accident, Julyk provided the load drop energy (in the form of drop height and equipment weight) necessary to cause dome failure. Han (1996) provided the radius of damage and the radius of the spalling. For the excess uniform or concentrated load accident, Han provided the failure load.

The amount of respirable material created as a result of the impact of the dropped or excessive load was determined after a review of a number of experiments regarding similar phenomena. The fraction transported from the surface, up into the dome and then out of the tank was determined from assumptions as no good model exists.

The steps of the calculation are:

1. Choose worst case load drop by choosing equipment that is the heaviest with the smallest impact area. Determine if dome is breached. Consider different tanks and equipment.

2. If dome is breached, obtain breach diameter and spall diameter.

3. Determine respirable fraction based on energy of the material that impacted the waste. The impact energy is calculated based on an assumption of free fall drop from the drop height. The area of the breach provides the area used in the volume affected. The affected depth is determined using equations from the field of soil mechanics (drops onto liquids are covered a little differently).

4. Determine the respirable quantity by multiplying the respirable fraction by the volume affected.

5. Determine the fraction that is transported out of the tank.

6. Determine the consequences.

3.0 As sumptions

a) It is assumed that the impact of the drop is onto dry saltcake. This assumption is made so as to maximize the doses (see Owczarski (1966) 
and Section 4.0 and 6.0 ) and so as to reduce the number of analyses that need to be performed. This assumption has however, some technical validity. Some double-shell tanks contain somewhat thick layers of "slush" (watery saltcake) covered by somewhat dry saltcake. Tank 101-SY is one of these with a 4 feet thick layer of saltcake ranging from very wet to quite dry. Since it will be shown that the penetration depth is about 1.4 feet, it is not overly conservative to call a 4 feet thick layer "dry saltcake." Tank AN-103 as well as some of the other Flammable Gas tanks also contain a floating saltcake.

This Calc Note covers SSTs, DCRTs, catch tanks, and 200 Series tanks. Load Drops into SSTs will have the same respirable quantity released as that from DSTs as the waste type and postulated drop height are the same. The respirable quantity from DCRTs and catch tanks will be less. This is because while the postulated drop height will be about the same (less for catch tanks), the waste stored is either all liquid or mostly liquid. Releases from the 200 Series tanks will be less as the postulated drop height is less (i.e., waste is closer to the surface).

b) It is assumed that the mixer pump weighs $20,0001 \mathrm{~b}$ based on data on the 101-SY mixer pump. The mixer pump in 101-AZ is heavier $(27,000 \mathrm{lb})$ but is not in the scope of the FSAR. Julyk (1996) also shows that this is the worst case equipment with regards to the. potential for dome breach. Some coverblocks are heavier but have larger impact areas and therefore less potential for dome breach.

c) For the unmitigated load drop case, the load is assumed to be dropped $25 \mathrm{~m}$. The height is based on

$7 \mathrm{~m}(23 \mathrm{ft})$ from dome to waste [corresponds to a waste volume of 800,000 gallons in a DST. About $2 / 3$ of the DSTs have this volume]

$2.5 \mathrm{~m}(8.2 \mathrm{ft})$ from dome to grade [the value for DSTs and a number of the SSTs]

$15.5 \mathrm{~m}(51 \mathrm{ft})$ from grade to the bottom of the pump [a conservative estimate of how high anyone would 7 ift a large load when there are no obstructions anywhere near that tall to 1 ift over].

While it is agreed that no operator would $1 \mathrm{ift}$ a pump $15.5 \mathrm{~m}(51 \mathrm{ft})$ above the surface, this drop height chosen so as to keep within the spirit of "unmitigated consequences."

d) The drop is assumed to occur into the pump pit as this is the weakest location (Julyk 1996).

e) For the unmitigated concentrated load case, a concentrated load of 600 tons is assumed to be parked directly on top of the tank. The load is the maximum the tank can withstand without failing (Han 1996). 
f) The unmitigated uniform and concentrated load case are not considered credible as Han (1996) states that an additional $30 \mathrm{ft}$ of soil as a uniform load or an additional 600 tons as a concentrated load must be placed over the tank to cause failure.

\subsection{Input Data}

The input data used is as follows

a) Mixer Pump weight 20,000 lb (based on 101-SY mixer pump)

b) Damage diameter 2 feet (based on Han 1996 for DSTs and SSTs).

c) Spall radius 5 feet (based on Han 1996). Han states that there is less spall for DSTs than there is for SSTs. However the effect of spall will be shown to be small.

d) ULDs are based on DST solids. Aging Waste Tanks do not have a floating saltcake/slush. The SST solids ULD is less than the DST solids ULD. It is assumed that the floating saltcake is comprised of DST solids.

\subsection{Calculations}

The first area studied is the fracture of solid material due to impact. DOE (1994) presents the respirable fraction for conditions under which a brittle material is crushed due to impact. The relationship is based on experiments in which small samples of glass, ceramics, and concrete were crushed by an impact hammer. The respirable fraction was determined with use of particle size counters. The respirable fraction is given by

$$
\mathrm{RF}=\mathrm{APgh}
$$

where

$$
\begin{aligned}
\mathrm{P} & =\text { specimen density, } \mathrm{g} / \mathrm{cm}^{3} \\
\mathrm{~g} & =\text { acceleration due to gravity } \\
& =980 \mathrm{~cm} / \mathrm{s}^{2} \\
\mathrm{~h} & =\text { drop height, cm } \\
\mathrm{A} & =\text { empirical correlation, } 2 \times 10^{-4} \mathrm{~cm}^{3} / \mathrm{J}
\end{aligned}
$$

This equation is unwieldy to use as it assumes that the material of concern falls from a height and fractures on impact. In our case, a pump falls onto the material of concern. Using data from DOE (1994), figure 4-13, the following empirical relation is obtained:

$$
R F=2 \times 10^{-4}\left(\mathrm{~J} / \mathrm{cm}^{3}\right)
$$

where

$$
\begin{aligned}
\mathrm{J} & =\text { impact energy, Joules } \\
\mathrm{cm}^{3} & =\text { volume affected by the impact, } \mathrm{cm}^{3}
\end{aligned}
$$

This is the form of equation (1) that is most useful to us. 
Jardine (1982) presents the results of brittle fracture studies. In this study, the specimens were made of brittle material (glasses, ceramics and concrete). The specimens were each about $2.54 \mathrm{~cm}$ diameter and $2.54 \mathrm{~cm}$ long. The specimens were contained between two steel plates with the axis horizontal. The plates and the specimens were placed in a sealed chamber. A $9.9 \mathrm{~kg}$ weight was dropped from specified heights onto the top stee 1 plate. Energy densities during impact were varied from 0.2 to $150 \mathrm{~J} / \mathrm{cm}^{3}$ with most tests between 1 and $10 \mathrm{~J} / \mathrm{cm}^{3}$. The fractured material was collected, sorted by size and measured.

Jardine (1982) also presents data for the fracture of coal due to impact. The data is quite close to the relationship of DOE's above.

Wallace et al. (1976) presents the results of impacts onto various formulations of concrete. The concrete specimens were $2.5 \mathrm{~cm}$ in diameter and $1.3 \mathrm{~cm}$ long. The concrete samples were crushed using an impact energy of $4.8 \mathrm{~kg}-\mathrm{m}$. In the $9.6 \mathrm{~kg}-\mathrm{m}$ tests the impact energy of $4.8 \mathrm{~kg}-\mathrm{m}(47 \mathrm{~J})$ was applied two times. The data is as follows:

\begin{tabular}{||l|c|c|c||}
\hline \multirow{2}{*}{ Concrete type } & \multirow{2}{*}{$\begin{array}{c}\text { \%aste in the } \\
\text { concrete }\end{array}$} & $7.4 \mathrm{~J} / \mathrm{cm}^{3}$ & $15 \mathrm{~J} / \mathrm{cm}^{3}$ \\
\cline { 3 - 4 } & 0 & Note 1 & 0.001 \\
\hline High alumina & 0 & Note 1 & 0.003 \\
\hline I-P & 0 & Note 1 & 0.001 \\
\hline Type II I & 40 & Note 1 & 0.001 \\
\hline High alumina & 40 & Note 1 & 0.007 \\
\hline I-P & \multicolumn{2}{|l}{} \\
\hline
\end{tabular}

Mecham (1981) provides impact data for other materials at energy densities of $1.2 \mathrm{~J} / \mathrm{cm}^{3}$. The data is

\begin{tabular}{||l|l|}
\hline \multicolumn{1}{|c|}{ Material } & \multicolumn{1}{|c|}{$\begin{array}{c}\text { Fraction less } \\
\text { than } 10 \text { microns }\end{array}$} \\
\hline Fused Quartz & $3.0 \mathrm{E}-04$ \\
\hline Crystalline Quartz & $3.0 \mathrm{E}-04$ \\
\hline Nepheline Syenite (a rock mineral with large grains) & $1.0 \mathrm{E}-04$ \\
\hline Sandstone & $7 \mathrm{E}-4$ \\
\hline $\mathrm{UO}_{2}$ & $3.0 \mathrm{E}-04$ \\
\hline
\end{tabular}

The respirable fraction as a function of energy is graphed in Figure 1 using all of the above data. The data shows values that are 2 to 3 times greater than that given by equation (2) taken from DOE (1994). However, the data is based on small, hard, but brittle specimens fractured by 
impact of a steel hammer while supported by a steel plate. In the waste tank, the distance between the impact load and the support plate are many meters apart (not $2.5 \mathrm{~cm}$ ). The waste is not hard and brittle throughout its depth. For "dry saltcake" tanks the waste is moist and flexible near the bottom of the tank, becoming less moist and less flexible near the surface and dry and hard at the top. It will be shown in the next portion of the writeup that the penetration depth is tens of centimeters not 2.5. A further reduction in respirable fraction over that shown in the bounding curve from Figure 1 can be shown by the following. The respirable quantity is obtained by multiplying the respirable fraction by the volume affected. The volume affected is the penetration depth times the impact area. The actual impact will create less respirable particles over the bottom portion of the waste penetrated due to energy absorption by the top portion. The respirable fraction in the top portion will be less due to energy absorption within the volume penetrated. Based on all of the above, it is believed that the respirable fraction should be given by the following equation taken from DOE (1994).

$$
R F=2 \times 10^{-4}\left(\mathrm{~J} / \mathrm{cm}^{3}\right)
$$

Use of the equation for respirable fraction requires knowledge of the volume that is affected. The affected volume is the area impacted times the depth in which the impact energy is absorbed. For dry saltcake the depth comes from Young (1969). Young studied earth penetration by projectiles. He considered blunt end projectiles falling from a variety of heights onto soils. In the case of a dome collapse, blunt ended pieces of concrete will also fall from a height. Therefore, Young's work is applicable for determining the volume of saltcake affected by the impact energy. The equation from Young (1969) for depth of penetration is

$$
Z=0.53 \mathrm{SN}(W / A)^{0.5} \ln \left[1+\left(2 \times 10^{-5}\right) V^{2}\right]
$$

where

$$
\begin{aligned}
Z= & \text { penetration depth, ft } \\
S= & \text { soil constant, a function of the soil. A value of } 10 \text { was } \\
& \text { chosen for dry saltcake to model a material with no } \\
& \text { cementation, low to moderate moisture and properties like } \\
& \text { topsoil, silt and clay mixtures and loose sand } \\
N= & \text { nose coefficient, } 0.72 \text { for blunt shapes } \\
W= & \text { projectile weight, ib } \\
A= & \text { area of the projectile, in }{ }^{2} \text { In this case the damage area. } \\
V= & \text { impact velocity, } \mathrm{ft} / \mathrm{sec} \\
= & (2 \mathrm{gh})^{0.5} \\
\mathrm{~h}= & \text { drop height, } \mathrm{ft} . \text { A value of } 25 \mathrm{~m} \text { or } 82 \mathrm{ft} \text { was used. } \\
\mathrm{g}= & 32.2 \mathrm{ft} / \mathrm{sec}^{2} .
\end{aligned}
$$

The depth affected is based on the damage diameter of $0.6 \mathrm{~m}(2 \mathrm{ft}$ ) (Han 1996). The area of damage is $0.3 \mathrm{~m}^{2}\left(3.1 \mathrm{ft}^{2}\right)$. 
Using a damage diameter of $0.6 \mathrm{~m}$ and the other data described above, the numerical values used to determine penetration depth are:

$$
\begin{aligned}
& S=10 \\
& N=0.72 \\
& W=20,0001 \mathrm{~b}+2.5 \mathrm{ft}(3.1)\left(1371 \mathrm{~b} / \mathrm{ft}^{3}\right) \\
&=21,000 \mathrm{lb} \\
& 20,0001 \mathrm{~b}=\text { pump weight }
\end{aligned}
$$

$2.5 \mathrm{ft}=$ thickness of dome plus pump pit floor (Julyk 1996). Each are 15 inches thick.

$137 \mathrm{lb} / \mathrm{ft}^{3}=$ concrete density based on specific gravity of 2.2.

$A=446 \mathrm{in}^{2}$ based on an area $3.1 \mathrm{ft}^{2}$

$\mathrm{h}=82 \mathrm{ft}$

$V=72.7 \mathrm{ft} / \mathrm{s}$

Solving for " $Z$ " yields $2.6 \mathrm{ft}$.

The volume affected is given by

$$
\begin{aligned}
V & =z\left(3.1 \mathrm{ft}^{2}\right) \\
& =8.0 \mathrm{ft}^{3} \\
& =2.3 \times 10^{5} \mathrm{~cm}^{3}
\end{aligned}
$$

Energy input is given by

$$
\begin{aligned}
E & =m g h \\
& =\left(9.8 \mathrm{~m} / \mathrm{s}^{2}\right)\left[\left(\frac{20,000 \mathrm{Ib}}{2.21 \mathrm{~b} / \mathrm{kg}}\right)(25 \mathrm{~m})+\left(\frac{1000 \mathrm{Ib}}{2.21 \mathrm{~b} / \mathrm{kg}}\right)(7 \mathrm{~m})\right] \\
& =2.3 \times 10^{6} \mathrm{~J}
\end{aligned}
$$

The energy density, $\mathrm{J} / \mathrm{cm}^{3}$ is found from

$$
\mathrm{J} / \mathrm{cm}^{3}=2.3 \times 10^{6} \mathrm{~J} / 2.3 \times 10^{5} \mathrm{~cm}^{3}=10 \mathrm{~J} / \mathrm{cm}^{3}
$$

The fraction made respirable is given by

$$
R F=2 \times 10^{-4}\left(10 \mathrm{~J} / \mathrm{cm}^{3}\right)=2 \times 10^{-3} \text {. }
$$

The quantity made respirable is given by

$Q=$ (Affected Volume) $\left(2 \times 10^{-3}\right)$ or $460 \mathrm{~cm}^{3}$ or rounding to the nearest tenth of a liter, $0.50 \mathrm{~L}$.

Spalling will add a small amount to the respirable quantity. Per discussions with F. C. Han (author of Han 1996), spalling will result in many small pieces falling to the waste. The thickness of these pieces will be about 1-2 inches, the approximate distance from the surface of the dome concrete to the first layer of reinforcing rod. A value of 0.1 feet ( 1.2 inches) will be used. The velocity at impact is based on a drop height of $7 \mathrm{~m}(23 \mathrm{feet})$ and is $39 \mathrm{ft} / \mathrm{s}$. The area of a spalled fragment is taken to be $1 \mathrm{ft}^{2}$. The weight of the fragment is $141 \mathrm{~b}$ using a volume of $0.1 \mathrm{ft}^{3}$ (specific gravity of 2.2). Solving for " $Z$ " yields 0.035 feet. 
The drop energy is:

$$
E=\left(\frac{14 l b}{2.2 I b / \mathrm{kg}}\right)\left(9.8 \mathrm{~m} / \mathrm{sec}^{2}\right)(7 \mathrm{~m})=440 \mathrm{~J}
$$

The respirable fraction is

$$
\begin{aligned}
R F & =2 \times 10^{-4}(440 \mathrm{~J}) /\left(0.035 \mathrm{ft}^{3}\right)(30.5 \mathrm{~cm} / \mathrm{ft})^{3} \\
& =9 \times 10^{-5}
\end{aligned}
$$

Assuming spaliing occurs totally over the 10 foot diameter area, the quantity made respirable is given by

$$
\begin{aligned}
\mathrm{RQ} & =9 \times 10^{-5}(0.035)\left(78.5 \mathrm{ft}^{2}\right)(30.5 \mathrm{~cm} / \mathrm{ft})^{3} \\
& =7 \mathrm{~cm}^{3} \\
& =0.007 \mathrm{~L} .
\end{aligned}
$$

The total made respirable is $0.51 \mathrm{~L}$.

The fraction of the respirable particles removed from the surface is determined next. It is assumed that waste is compressed by the impact and rebounds when the pump rebounds. There is also assumed to be air flow out from under the rebounded concrete and pump. The compression, rebound and airflow results in some of the newly made respirable material being removed from the surface.

The fraction of this newly created respirable particulate that is removed from the surface is considered next. One possible model for particulate suspension is that the newly made respirable particles responds to compression followed by depressurization in the same way that pressurized powders do. From DOE (1994), the fraction made airborne from rapidly depressurizing powder that was pressurized to $6.9 \mathrm{MPa}$ (500 to 1,000 psi) is 0.05 to 0.1 .

Another potential mechanism for removal from the surface is to assume that compression followed by rebound results in accelerated air flow along the surface between the debris and the waste prior to the pump coming to rest on top of the waste and debris. That is the pump impacts the waste and creates respirable particles. The pump rebounds off the waste. Air rushes in and suspends some of the newly created particulate. The pump falls again onto the waste and comes to rest. The process of falling the second time creates additional air flow out from under the pump. Mishima provides an airborne release fraction of $5 \times 10^{-3}$ for the suspension of powders due to accelerated flow parallel to the surface from an explosion. He provides a value of 0.1 for the suspension of powder due to a deflagration above the powder.

Use of these models suggests that it is reasonable to assume that 0.1 of the respirable particles are suspended during the rebound.

Suspended particles will likely be removed from the air after the debris settles following the rebound. This fraction is difficult to determine 
as it is a function of the velocity of the air under the debris as it falls to the surface, the number of chunks of debris (assuming the suspended material can flow up along the sides of the chunk), whether the chunks fall together or at different speeds and the amount of respirable suspended on the second impact with the surface. This is difficult to determine. For conservatism, it will be assumed that all suspended material is transported out from under the debris into the dome space. That is, there is no removal of material under the falling, rebounded debris.

The suspended material is transported into the dome. The material is moving horizontally around the edges of the debris and vertically through the space between adjacent pieces of the debris due to circulation caused by the air moving in under the rebounded pump and moving out when the pump settles. This circulation will spread the lifted material throughout the dome. There will be an initial concentration gradient with the high concentration being directly above and to the side of the debris and the concentration at the walls at nearly zero. In time, the concentration will become more uniform.

The release of the suspended material out of the tank will take place via an initial puff release. The puff release comes about due to the sudden volume change as a result material entering the tank. The volume is of the debris is $0.7 \mathrm{~m}^{3}$. It is made up of the volume that the pump occupies $\left(0.5 \mathrm{~m}^{3}\right.$ based on a $1 \mathrm{ft}$ diameter, $23 \mathrm{ft}$ of the $30 \mathrm{ft}$ pump), and the volume of the concrete; $0.2 \mathrm{~m}^{3}$ (based on $2.5 \mathrm{ft}$ thick and $3.1 \mathrm{ft}^{2}$ area).

Assume that the suspended material is initially contained within a volume inscribed by a cylinder 2 times the diameter of the opening in the dome and as tall as the dome; or a $4 \mathrm{ft}$. diameter and $23 \mathrm{ft}$. tall cylinder. The volume of this cylinder is $8.2 \mathrm{~m}^{3}\left(289 \mathrm{ft}^{3}\right)$. The volume of the debris is $0.7 \mathrm{~m}^{3}$ or $25 \mathrm{ft}^{3}$. The puff release is conservatively based on the volume change as a result of $25 \mathrm{ft}^{3}$ of debris entering a volume of $289 \mathrm{ft}^{3}$. The fraction of material in the puff release is $25 / 289$ or 0.09 . This value appears to be quite large given the small opening in the dome. It is left conservatively large to account for uncertainties and to account for additional longer term release due to air flow over the tank drawing the material out after the puff release has ended. No credit is taken for flow through the ventilation system. Flow rates are typically quite small as compared to dome space and the dome damaged area is large enough that a vacuum cannot be drawn to the tank.

Given the above, the respirable quantity released is given by:

$$
R Q=(0.51 \mathrm{~L} \text {, respirable })(0.1 \text { suspended })(0.09 \text {, removed })=0.005 \mathrm{~L}
$$

Consequence Analysis. The consequences are based on impact onto dry saltcake in a DST. The ULD is based on DST solids. 
The onsite dose is found using the methodology in SARR-016 and Cowley (1996). The inhalation dose is given by

$$
\text { Dose }=(L \text {, released })(x / Q)(B R)(U L D)
$$

where

$x / Q=$ is the atmospheric dispersion factor for short releases (i.e., no plume meander, sec/m (see below)

$B R=$ is the breathing rate

$=3.3 \times 10^{-4} \mathrm{~m}^{3} / \mathrm{sec}$ for short duration releases

ULD $=$ is the unit 1 iter dose

$=5.3 \mathrm{E}+5 \mathrm{SV} / \mathrm{L}$ (Cowley 1996)

$L$, released $=1$ iters of respirable material released to the environment

$=0.005$

The inhatation does are

$\begin{array}{lcccc} & \text { Location } & X / Q & \text { Sv } & \text { Rem } \\ \text { Onsite } & 100 \mathrm{~m} \mathrm{E} & 3.41 \mathrm{E}-2 & 0.03 & 3 \\ \text { Offsite } & 8760 \mathrm{~m} \mathrm{~N} & 2.83 \mathrm{E}-5 & 3 \mathrm{E}-5 & 0.003\end{array}$

The offsite ingestion dose is found from the following (Cowley 1996)

Dose $=(L$, released $)(x / Q)(U L D$, ingestion $)$

where

$$
\text { ULD ingestion }=0.48 \mathrm{~Sv}-\mathrm{m}^{3} / \mathrm{s}-\mathrm{L}
$$

The offsite ingestion dose is 7 E-8 Sv or 7 E-6 rem.

The total dose is

$$
\begin{array}{lll}
\text { Onsite } & 3 \text { rem or } & 30 \mathrm{mSv} \\
\text { Offsite } & 0.003 \text { rem } & 0.03 \mathrm{mSv}
\end{array}
$$

The toxicological consequences are arrived at by a calculation using the "sum-of-fractions" technique. Load drops are considered to be "Unlikely" as much care is usually taken lifting large loads (more details are found in the FSAR, Section 3.4.2.1). For the "Unlikely" Category, SARR-011 (Van Keuren 1996), for DST solids and a puff release the sum-of-fractions value is

$$
\begin{array}{ll}
\text { Onsite } & 970 \mathrm{~L}^{-1} \\
\text { Offsite } & 0.059 \mathrm{~L}^{1}
\end{array}
$$


The toxicological consequences are found from

$$
\text { Tox }=(L \text {, released })\left(\text { sum-of-fraction, } L^{-1}\right) \text {. }
$$

Using these value to toxicological consequences are:

\section{Toxicological}

Consequences

\section{Quantity \\ released Onsite offsite

$0.005 \mathrm{~L} \quad 5 \quad 3 \mathrm{E}-4$

The onsite values for SST solids (even though mixer pumps will not be placed in SSTs) is six times larger and the offsite value is twice as large.

\section{Whole Dome Collapse (Beyond Design Basis Event)}

Assume a 600 ton load was parked on top of the dome. Han (1996) states that the dome could fail given this condition. The same methodology, general assumptions, and calculational steps as were used above are used here.

The drop height is 23 feet $(7 \mathrm{~m})$. This is the height from the top of the dome to the waste.

The impact area (for use in determining " $Z$ " and respirable quantity) is $4418 \mathrm{ft}^{2}$ (75 feet diameter)

$$
\text { or } 6.4 \mathrm{E}+5 \mathrm{in}^{2} \text {. }
$$

The weight for use in determining " $Z$ " and impact energy is a combination of the 600 ton load and $8 \mathrm{ft}$ of soil. The density of soil is $1371 \mathrm{~b} / \mathrm{ft}^{3}$ (a conservatively high value based on Han 1996). The weight is

$$
\begin{aligned}
W & =600 \text { ton }(20001 \mathrm{~b} / \text { ton })+\left(4418 \mathrm{ft}^{2}\right)(8 \mathrm{ft})\left(1371 \mathrm{~b} / \mathrm{ft}^{3}\right) \\
& =1.2 \mathrm{E}+61 \mathrm{~b}+4.84 \mathrm{E}+61 \mathrm{~b} \\
& =6 \mathrm{E}+61 \mathrm{~b} .
\end{aligned}
$$

Solving for " $Z$ " using equation 4 yields 0.34 feet.

The affected volume is

$$
V=0.34\left(4418 \mathrm{ft}^{2}\right)=150 \mathrm{ft}^{3}
$$

The impact energy is given by

$$
E=(6 E+61 \mathrm{~b})\left(9.8 \mathrm{~m} / \mathrm{sec}^{2}\right)(7 \mathrm{~m}) /(2.2 \mathrm{lb} / \mathrm{kg})=1.9 \mathrm{E}+8 \mathrm{~J}
$$

The respirable fraction is given by

$$
\begin{aligned}
& R F=2 \times 10^{-4}\left(\mathrm{~J} / \mathrm{cm}^{3}\right)=2 \times 10^{-4}(1.9 \mathrm{E}+8 \mathrm{~J}) /\left(1502 \mathrm{ft}^{3}\right)(30.5 \mathrm{~cm} / \mathrm{ft})^{3} \\
& =8.9 \mathrm{E}-4 \text {, or rounded to } 9 \mathrm{E}-4
\end{aligned}
$$


The respirable quantity is given by

$$
\begin{gathered}
\left.R Q=(9 E-4) 1502 \mathrm{ft}^{3}\right)(30.5 \mathrm{~cm} / \mathrm{ft})^{3}=3,8 \mathrm{E}+4 \mathrm{~cm}^{3} \\
=38 \mathrm{~L}
\end{gathered}
$$

In the previous pump drop analysis, $10 \%$ of that made respirable was removed from the surface and $100 \%$ of that was transported above the debris due to the scrubbing and trapping action of the soil. In this case, 8 feet of soil also falls into the tank. The soil will act to scavenge the respirable material made and lofted by the impact. It is assumed that $90 \%$ of the respirable material scavenged. Therefore the quantity of respirable material that gets transported above the debris is

$$
Q=38 \mathrm{~L}(0.1)(0.1)=0.38 \mathrm{~L} \text {. }
$$

It is assumed that all of this material is transported to the environment.

The consequences are 76 times those for the load drop case. The onsite dose would be $228 \mathrm{rem}$ and the offsite dose would be $0.2 \mathrm{rem}$.

\subsection{Sensitivity to Key Parameters and Assumptions}

Drop heights. The dose is directly proportional to drop height. The energy of the impact is directly proportional to drop height. The impact velocity is proportional to the square root of the drop height. The depth of penetration is proportional to the drop height as

$$
\ln \left[1+\left(2 \times 10^{-5}\right) v^{2}\right] \cong 2 \times 10^{-5} v^{2} .
$$

Therefore the respirable fraction is unchanged by drop height. The respirable quantity is given by:

$$
R Q=R F(A)(Z) \text { (density) }
$$

Since "RF", "A" and "density" are unaffected by drop height and " $Z$ " is proportional to drop height, the respirable quantity is proportional to drop height.

Drop Weight. The dose is proportional to the weight dropped. The energy is directly proportional to weight. The depth of penetration is proportional to the square root of the weight. The respirable fraction is proportional to the square root of the weight. The respirable quantity is therefore proportional to the weight.

Liquid Surface vs Solid Surface. If the surface is a liquid, the release fraction is different. The release fraction for the impact of concrete and debris onto a liquid surface is assumed to be the same as if the liquid hit the debris.

No good method exists for determining the respirable fraction for heavy loads impacting pools. The model used here is as close as one can easily get (personal communication with J. Mishima and P. Owczarski). The model 
is based on experiments performed in Ballinger (1988). In those experiments it was observed that most of the respirable droplets were created as the liquid spread over the solid surface. It is therefore concluded that the impact energy acted on the liquid film creating the respirable droplets. Based on this result, it is also assumed that if the impact was due to the solid surface striking the liquid, the respirable quantity would also come from the liquid film.

The equation for the airborne release fraction for the spill of liquid onto an unyielding surface (from Ballinger 1988, Owczarski 1996) is

$$
A R F=(8.12 E-10)(A R C H)^{0.55}
$$

where

$$
\begin{aligned}
\text { ARCH } & =\text { the Archimedes number } \\
& =\rho_{a}^{2} \mathrm{H}^{3} \mathrm{~g} / \mathrm{u}^{2} \\
\rho_{a} & =\text { density of air, } \mathrm{g} / \mathrm{cm}^{3} \text { or } \mathrm{kg} / \mathrm{m}^{3} \\
H & =\text { modified drop height, } \mathrm{cm} \text {, or } \mathrm{m} \\
\mathbf{g} & =980 \mathrm{~cm} / \mathrm{s}^{2}, \text { or } 9.8 \mathrm{~m} /{ }^{2} / \mathrm{s} \\
\mathbf{u} & =v i s c o s i t y, \text { poise, or } \mathrm{kg} / \mathrm{m}^{-5} .
\end{aligned}
$$

The respirable fraction is 0.54 (Owczarski 1996). The values of ARF and RF are applied to a volume described by the area of the debris and a thickness was $1 \mathrm{~mm}$ in Owczarski (1996). In this analysis a value of $3 \mathrm{~mm}$ is used as that is the thickness of a film of tank liquid if allowed to spread out on a flat surface.

For the case being studied, the $25 \mathrm{~m}$ drop, the ARF is found to be 0.002 assuming a waste viscosity of $2 \mathrm{cp}$ and waste density of $1.3 \mathrm{~g} / \mathrm{cm}^{3}$ $\left(81,1 \mathrm{~b} / \mathrm{ft}^{3}\right)$. Using a value for RF of 0.54 , the respirable fraction is $10^{-3}$.

The film volume is

$$
V=\left(1,800 \mathrm{in}^{2}\right)(2.54 \mathrm{~cm} / \mathrm{in})^{2}(0.3 \mathrm{~cm})=3,484 \mathrm{~cm}^{3}
$$

The quantity made respirable is

$$
Q=10^{-3}\left(3,484 \mathrm{~cm}^{3}\right)=3.5 \mathrm{~cm}^{3} \text { or } 0.004 \mathrm{~L}
$$

This is a much smaller value than that for solids. Changes in viscosity affect the release in about the ratio of the viscosities. If the viscosity was $30 \mathrm{cp}$ (101-SY liquids) the respirable quantity released in the $25 \mathrm{~m}$ drop case are $4 \times 10^{-5} \mathrm{~L}$.

Given this type of event the consequences for the case when the DCRT holds liquid would be no worse than that for the load drop into a DST or SST containing liquid, as the drop heights, weight and damage areas are similar. Should these tanks just contain the heel, the consequences would be less than those for a DST or SST containing saltcake. 


\subsection{Results}

\section{Load Drop}

The onsite dose is below the Guidelines for an Unlikely Event. The Guideline dose is 5 rem. The offsite dose is well below the Guideline value of $0.5 \mathrm{rem}$.

The onsite toxicological consequences exceed the Guideline value of 1.0 . The offsite toxicological consequences are well within the Guideline value of 1.0 .

\section{Excess Concentrated Load}

The onsite dose exceeds the Guidelines for any frequency event. However, the event is not considered credible. The calculation was performed in case it is needed for a "Beyond Design Basis Event."

\subsection{Important Assumptions and Parameters}

The 20,000 1b mixer pump has the worst case (with regards to dome penetration) combination of weight and impact area. No other equipment within the scope of the FSAR has a combination worse than this (Julyk 1996). Some coverblocks are heavier but have larger surface areas. 


\subsection{References}

Han, F. C.,1996, Topical - Structural Integrity and Potential Failure Modes of the Hanford High-Level Waste Tanks, WHC-SD-TWR-RPT-002, Westinghouse Hanford Company, Richland, Washington. DRAFT

Julyk, L. J., Load Drop Calculations DRAFT

DOE, 1994, Airborne Release Fractions/Rates and Respirable Fractions for Non-reactor Nuclear Facilities, DOE-HDBK-3010-94, U.S. Department of Energy, Washington DC.

Young,C. W., 1969, Depth Prediction for Earth Projectiles Report, Journal of Soil Penetrating Mechanisms and Foundations, Proceedings of the American Society of Civil Engineers, Volume 95, May 1969.

Jardine, L. J., Mecham, W. J., Reedy, G. T., Steindler, M. J., 1982, Final Report of Experimental Laboratory - Scale Brittle Fracture Studies of G7asses and Ceramics, ANL-82-39, Argonne National Laboratory, Argonne, Illinois.

Wallace, R. M., and J. A. Kelley, 1976, An Impact Test for Solid Waste Farms, DP-1400, DuPont Savannah River Laboratory, Aiken, South Carolina.

SARR-016, 1996, Tank Waste Compositions and Atmospheric Dispersion Coefficients for Use in ASA Consequence Assessments, WHC-SD-WM-SARR-016, Rev. 2, Westinghouse Hanford Company, Richland, Washington.

Cowley, W. L., 1996, Development of Radiological Concentrations and Unit Liter Doses for TWRS FSAR Radiological Consequence Calculations, WHC-SD-WM-SARR-037, Rev. 0, Westinghouse Hanford Company, Richland, Washington.

Owczarski, P. C., and J. Mishima, 1996, Airborne Release/Respirable Fractions for Dome Collapse in HLW Tanks, Science Applications International Corp., Richland, Washington.

Ballinger, M. Y., J. W. Buck, P. C. Owczarski, and J. E. Ayer, 1988, Methods for Describing Airborne Fractions of Free $\mathrm{Fa} 7 \mathrm{l}$ Spills of Powders and Liquids, NUREG/CR-4997, U.S. Nuclear Regulatory Commission, Washington, D.C.

Mecham, W. J., L. J. Jardine, R. H. Pelto, G. T. Reedy, and M. J. Steindler, 1981, Interim Report of Brittle-Fracture Impact Studies: Development of Methodology, ANL-81-27, Argonne National Laboratory, Argonne, Illinois. 
Figure 1
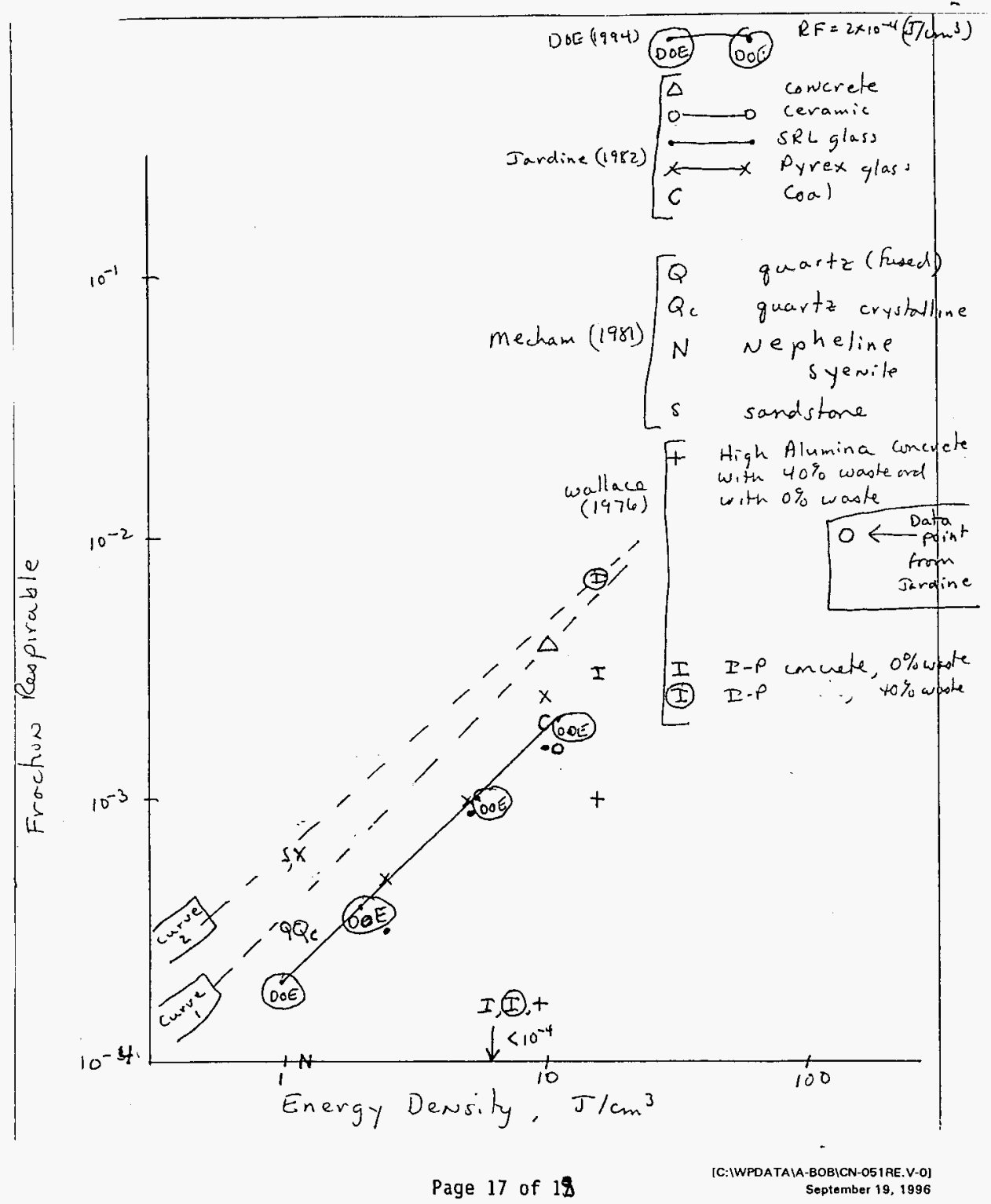
$\omega H C-S D-\omega M-C N-0 N-1$, A.ev

\section{CHECKLIST FOR PEER REVIEW}

Document Reviewed: The Effects of Load Drop, Uniform Load and Concentrated Load on Waste Tanks. WHC-SD-WM-CN-051, Rev.1

Scope of Review: Reviewed calculations, checked references, and reviewed assumptions and models. The models used for release of material from the tank and for calculating the respirable fraction for solids hitting a liquid are very conservative. However they do establish a bounding case which has consequences that are within radiological risk acceptance guidelines. The onsite toxicological risk acceptance guideline is exceeded. Refinement of the models and/or some of the assumptions could reduce the toxicological consequences.

$\frac{\text { Yes } \text { No }_{0} \text { NA }}{[\mathrm{x}][\mathrm{J}[\mathrm{C}}$ *

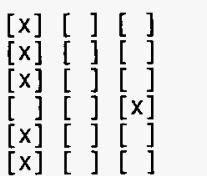

[x] [ ] [ ]

[x] [ ] [ ]

$[x][$ ] [ ]

[]$\left[\begin{array}{ll}{[} & {[\mathrm{x}]} \\ {[} & {[\mathrm{x}]}\end{array}\right.$

[ ] [ ] $[\mathrm{x}]$

[x] [ [ ] [ [ [ ]

[x] [ ] [ ]

[ ] [ ] $[\mathrm{x}]$

[ ] $[\mathrm{x}]$ *
Previous reviews complete and cover analysis, up to scope of this review, with no gaps.

Problem completely defined.

Accident scenarios developed in a clear and logical manner. Necessary assumptions explicitly stated and supported. Computer codes and data files documented.

Data used in calculations explicitiy stated in document.

Data checked for consistency with original source information as applicable.

Mathematical derivations checked including dimensional consistency of results.

Models appropriate and used within range of validity or use outside range of established validity justified.

Hand calculations checked for errors. Spreadsheet results should be treated exactly the same as hand calculations. Software input correct and consistent with document reviewed. Software output consistent with input and with results reported in document reviewed.

Limits/criteria/guidelines applied to analysis results are appropriate and referenced. Limits/criteria/guidelines checked against references.

Safety margins consistent with good engineering practices. Conclusions consistent with analytical results and applicable limits.

Results and conclusions address all points required in the problem statement.

Format consistent with appropriate NRC Regulatory Guide or other standards

Review calculations, comments, and/or notes are attached.

\section{[x] [ ] [ ] Document approved.}

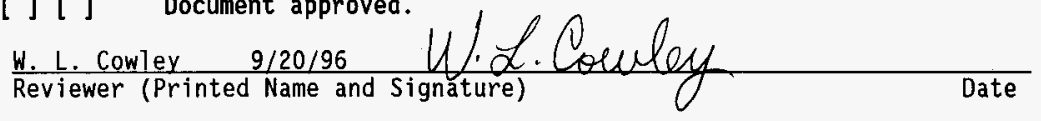

* Any calculations, comments, or notes generated as part of this review should be signed, dated and attached to this checklist. Such material should be labeled and recorded in such a manner as to be intelligible to a technically qualified third party. 


\section{DISTRIBUTION SHEET}

\begin{tabular}{|c|c|c|c|c|c|}
\hline \multirow{2}{*}{$\begin{array}{l}\text { To } \\
\text { Distribution }\end{array}$} & \multirow{2}{*}{\multicolumn{3}{|c|}{$\begin{array}{l}\text { From } \\
\text { R. M. Marusich }\end{array}$}} & \multicolumn{2}{|l|}{ Page 1 of 1} \\
\hline & & & & \multicolumn{2}{|c|}{ Date $9 / 19 / 96$} \\
\hline \multicolumn{4}{|l|}{ Project Title/Work Order } & \multicolumn{2}{|l|}{ EDT No. } \\
\hline \multicolumn{4}{|c|}{$\begin{array}{l}\text { The Effects of Load Drop, Uniform Load and Concentrated Load on } \\
\text { Waste Tanks }\end{array}$} & \multicolumn{2}{|c|}{ ECN No. 634490} \\
\hline Name & MSIN & $\begin{array}{l}\text { Text } \\
\text { With All } \\
\text { Attach. }\end{array}$ & Text Only & $\begin{array}{l}\text { Attach./ } \\
\text { Appendix } \\
\text { Only }\end{array}$ & $\begin{array}{l}\text { EDT/ECN } \\
\text { Only }\end{array}$ \\
\hline E. R. Bruschi & $A 2-34$ & $x$ & & & \\
\hline C. Carro & $A 2-34$ & $x$ & & & \\
\hline W. L. Cowley & A3-37 & $x$ & & & \\
\hline D. S. Leach & $A 3-34$ & $x$ & & & \\
\hline R. M. Marusich (3) & $A 3-34$ & $x$ & & & \\
\hline TWRS S \& L Project Files (2) & A2-26 & $x$ & & & \\
\hline Central Files (original +2 ) & A3-88 & $x$ & & & \\
\hline
\end{tabular}

